\section{Use of sheep erythrocytes as solid phase supports in double antibody immunoassay systems}

JOHN KANE AND ERIC GOWLAND Department of Chemical Pathology, University Hospital of South Manchester, Manchester, UK

There is a growing trend to use antibodies coupled to insoluble support materials to facilitate the separation of antigen-antibody complexes from antigen in radioimmunoassay (RIA) procedures. Materials most widely employed are polymers, such as polystyrene and agarose. Usually a suspension of fine beads is used. Alternatively, antibodies may be attached to the walls of the polystyrene tubes in which the assay is to be carried out.

Erythrocytes have a number of properties that make them suitable for use as insoluble supports, and they have been extensively used over many years in passive haemagglutination procedures. They do not appear to have gained popularity as reagents for RIA, although Luner (1975) has described an insulin assay in which he used antibodies coupled to cells by the chromic chloride technique.

Erythrocytes have a small size that gives them a large surface area to volume ratio and, in addition, permits them to stay in suspension for a reasonable length of time without continual agitation. Their uniformity of size results in even settling. They are inexpensive and readily obtainable.

A further advantage possessed by red cells is that they are themselves antigenic. Consequently, it is possible to use an immunochemical procedure for coupling antibodies to them that is less damaging than chemical procedures. For example, to couple donkey anti-rabbit gammaglobulin antibodies to sheep red cells (SRBC), the cells are first treated with rabbit anti-SRBC antiserum to produce a coating of rabbit gammaglobulin (anti-SRBC antibody). The coated cells are then exposed to an excess of gammaglobulin antiserum to give a second coating with antibodies that are capable of binding further molecules of rabbit gammaglobulin.

We have used antibody-coated SRBC for over a year and have found the technique to have advantages over conventional assay procedures employing antibody in solution. In this report we shall describe their use in an RIA for growth hormone (HGH) as a model system.

Received for publication 18 September 1978
Material and methods

PREPARATION OF TANNED SHEEP RED CELLS The procedure employed was based on that of Avrameas et al. (1969). SRBC were washed in three changes of phosphate buffered saline (PBS) and then made up a $10 \%$ suspension in $0.15 \mathrm{M}$ phosphate buffer, $\mathrm{pH} 7 \cdot 4$. The cells were maintained in suspension by a magnetic stirrer while an aqueous solution of $5 \%$ glutaraldehyde was slowly added (100 $\mu \mathrm{l} / \mathrm{ml}$ cell suspension). Stirring was continued for a further 4 hours and then the cells were washed with three changes of PBS.

COATING OF TANNED CELLS WITH ANTIBODIES

Glutaraldehyde-activated cells were made up as a $10 \%$ suspension in PBS, and rabbit anti-SRBC serum (VD15 lot K5538, Wellcome Reagents Ltd) was added ( $5 \mu \mathrm{l} / \mathrm{ml}$ cell suspension). The cells were gently stirred for 18 hours and then washed three times in PBS. The cells were again made up as a $10 \%$ suspension, and donkey anti-rabbit globulin serum (RD17 lot K5579/1, Wellcome Reagents Ltd) was added (10 $\mu \mathrm{l} / \mathrm{ml}$ cell suspension). Stirring was carried out for a period of 4 hours, and the cells were then washed with three changes of PBS. The antibody-coated SRBC were stored as a $10 \%$ suspension in PBS containing $1 \mathrm{~g} / 1$ of bovine serum albumin (BSA) $+1 \mathrm{~g} / 1$ of thiomersal.

$N B$ The final quantities of antisera added to the cells were determined in preliminary titration experiments in which the concentrations of each antiserum were varied in turn. The efficiency of coating in these experiments was assessed by the capacity of cells to bind rabbit anti-HGH molecules that had formed soluble complexes with 125I-labelled HGH (as used in the 'zero' tube of the RIA but with normal rabbit serum omitted).

\section{RIA OF GROWTH HORMONE}

HGH iodination material (69/46) and HGH standard (1st International Reference Preparation) were both provided by the National Institute for Medical Research. Iodination was carried out by the chloramine $\mathbf{T}$ method. Rabbit anti-HGH serum was a gift from Professor J. Landon.

Briefly, the protocol for the double antibody technique is as follows:

1 Mix $100 \mu$ l of specimen with $200 \mu$ l of rabbit anti-HGH serum, prediluted $1: 180000$ in assay buffer $(0.05 \mathrm{M}$ barbitone, $\mathrm{pH} 8 \cdot 6$, containing $1 \mathrm{~g} / 1$ of BSA) to which normal rabbit serum (NRS) had been added to a concentration of $0.25 \%$.

2 Incubate overnight at $4^{\circ}$. 
3 Add $200 \mu \mathrm{l}$ of ${ }^{125}$ I-labelled HGH in assay buffer.

4 Incubate overnight at $4^{\circ}$.

5 Add $100 \mu 1$ of donkey anti-rabbit globulin serum diluted $1: 30$ with assay buffer.

6 Incubate overnight at $4^{\circ}$.

7 Add $3 \mathrm{ml}$ of cold saline.

8 Centrifuge at $4^{\circ} \mathrm{C}$ for 30 minutes.

9 Decant the supernatant fluid and count the radioactivity in the precipitate.

The assay employing the antibody-coated SRBC is similar to that described above, except for the following modifications:

1 NRS is omitted from the buffer containing the antiserum added in step 1.

$2100 \mu \mathrm{l}$ of a suspension in PBS of antibodycoated SRBC is added instead of second antibody solution in step 5 .

3 Centrifugation is for 10 minutes in step 8 .

Other modification of the procedure will be noted in the text.

\section{Experiments and results}

A number of preliminary experiments were carried out to establish the optimum conditions for use of the antibody-coated SRBC.

First, an assay was set up in which the concentration of SRBC in the suspension used in step 5 was varied. A series of tubes were also set up with antiHGH serum replaced by an equal concentration of NRS in order to test for nonspecific binding of the labelled HGH by the antibody-coated sheep cells. The results of this experiment are shown in Fig. 1, from which it was decided to use a $0.75 \%$ suspension of antibody-coated SRBC in PBS for future assays in order to ensure an excess of second antibody. Nonspecific binding is negligible at this concentration of cells.

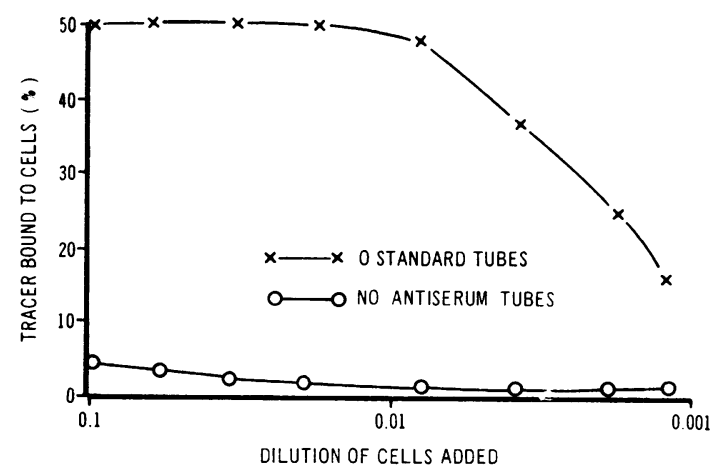

Fig. 1 Uptake of growth hormone label/antiserum complex onto donkey anti-rabbit serum-coated cells.

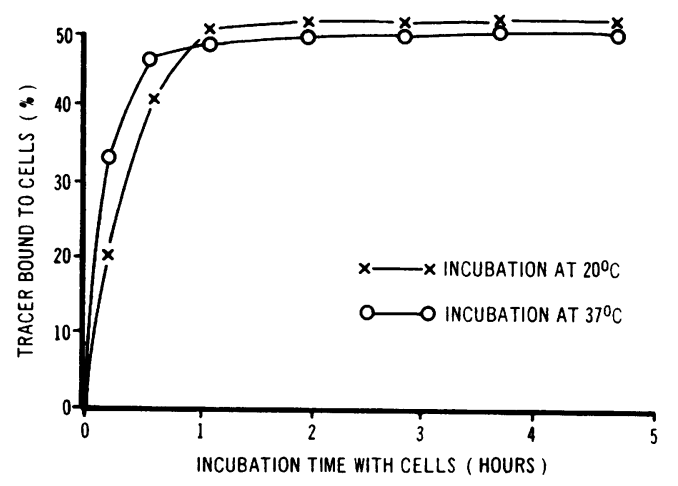

Fig. 2 Time of uptake of growth hormone label/ antiserum complex onto donkey anti-rabbit serumcoated cells.

Figure 2 shows the results of an experiment in which the reaction with antibody-coated SRBC was carried out at room temperature and at $37^{\circ}$. In addition, the time of incubation was also varied. The assay tubes were agitated at approximately half-hour intervals to resuspend the SRBC. From this experiment it was decided to use incubation at room temperature for a period of one hour. Subsequently, it was found unnecessary to resuspend the SRBC during the hour following the initial mixing.

A comparison of the results obtained with the red cell assay compared to those obtained with the double antibody technique is shown in Figure 3.

Variation within and between assays was assessed by performing replicate determinations on serum pools. Results for a single specimen measured 15

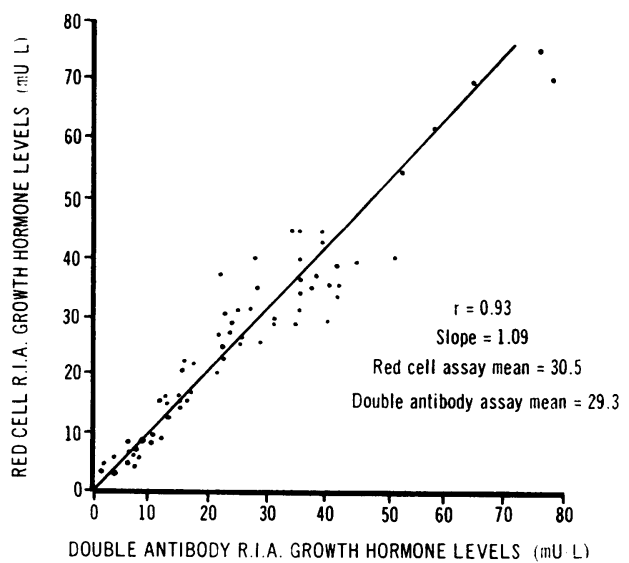

Fig. 3 Comparison of double antibody and red cell growth hormone assays. 
times in the same assay gave a mean and standard deviation of $13.2 \pm 0.87 \mathrm{mU} / 1$ when red cells were used, and $13.0 \pm 0.78 \mathrm{mU} / 1$ with the conventional assay. Two pools measured 10 times in separate assays gave values of $8.6 \pm 1.91 \mathrm{mU} / 1$ and $17.4 \pm$ $2.43 \mathrm{mU} / 1$ with the red cell technique, and $8.3 \pm$ $1.61 \mathrm{mU} / 1$ and $17 \cdot 1 \pm 2.93 \mathrm{mU} / 1$ with the double antibody method.

\section{Discussion}

The results obtained by the solid phase double antibody technique are in agreement with those obtained by the conventional assay, and the precision of the two methods is similar. However, while there is little to choose between the two assays as far as the quality of results is concerned, there are technical advantages to be gained from the use of red cells.

There is a considerable reduction in the amount of second antibody required. In the assay described above, for example, $1 \mathrm{ml}$ of donkey anti-rabbit serum, when coupled to SRBC, is sufficient material for 6000 assay tubes, whereas, when used in the standard double antibody technique, $1 \mathrm{ml}$ of the same antiserum is sufficient for only 400 assay tubes. A further advantage is that the times required for incubation and centrifugation are both shortened when antibody-coated SRBC are used.

The main disadvantage of the use of antibodycoated SRBC is that their preparation requires a third antibody. However, the cost of this antibody is relatively low and is more than offset by the savings in the cost of second antibody. A second disadvantage is that the use of red cells is restricted to assays in which the first antibody is used in high dilution. Obviously, the amount of gammaglobulin that the antibody-coated SRBC can absorb is limited and is likely to be exceeded in assays in which the first antibody has a titre of less than about 1000 .

The antibody-coated SRBC technique can, of course, be used in assays other than those employ- ing a rabbit first antibody and a donkey second antibody. All that is required is that the antisera employed should be raised in appropriate species. For example, an assay employing a guinea-pig serum as the first antibody would require anti-SRBC serum raised in the guinea-pig instead of in the rabbit.

Finally, two practical points are worth noting. Firstly, antibody-coated SRBC are suitable for use in automated techniques employing pipetting stations or continuous-flow systems. Secondly, their stability makes them convenient reagents for routine use. Tanned cells are stable for at least a year. We have not stored antibody-coated cells for more than about four months because of a high rate of usage. However, we have found no evidence of their deterioration during that priod, and it is likely that they can be stored for longer periods. We check the immuno-absorptive capacity of the cells whenever the coating procedure is carried out, and we have found it unnecessary to re-titrate the antisera, even when a new batch of tanned cells is introduced. Obviously, new batches of antisera need to be titrated.

In addition to the HGH assay, antibody-coated SRBC are used in our routine RIA for gonadotrophins.

\section{References}

Avrameas, S., Taudou, B., and Chuilon, S. (1969). Glutaraldehyde, cyanuric chloride and tetraazotized $o$-dianisidine as coupling ragents in the passive hemagglutination test. Immunochemistry, 6, 67-76.

Luner, S. J. (1975). Continuous flow automated radioimmunoassay using antibodies attached to red blood cells. Analytical Biochemistry, 65, 355-361.

Requests for reprints to: Dr E. Gowland, Department of Pathology, Withington Hospital, West Didsbury, Manchester M20 8LR, UK. 